\title{
ENZYMATIC PROPERTIES OF MALT CARBOXYPEPTIDASE II IN HYDROLYSIS AND AMINOLYSIS REACTIONS
}

\author{
by
}

\author{
KLAUS BREDDAM
}

\author{
Department of Chemistry, Carlsberg Laboratory, \\ Gamle Carlsberg Vej 10, DK-2500 Copenhagen Valby
}

Keywords: Barley, malt, carboxypeptidase, peptide synthesis

\begin{abstract}
Carboxypeptidase II from malted barley is a serine carboxypeptidase which exhibits peptidase activity with a pH optimum below 4.0 and amidase, esterase, and peptidyl amino acid amide hydrolase activities with a pH optimum above 7.5. These different $\mathrm{pH}$-optima reflect variations of the $\mathrm{pH}$ dependence of $\mathrm{K}_{\mathrm{m}}$. The enzyme hydrolyses effectively substrates containing basic and hydrophobic amino acid residues on the $P_{1}$ and/or $P_{1}^{\prime}$ positions. Addition of salt or phenylguanidine inhibits the activity towards substrates with basic amino acid residues in either of these positions and enhances the activity towards peptide substrates with hydrophobic amino acid residues in both positions and towards ester substrates with hydrophobic amino acid residues in the $P_{1}$ position. A binding site model to account for the observations is proposed.

Malt carboxypeptidase II catalyses the formation of peptide bonds using an N-blocked amino acid ester as acyl component and amino acids, amino acid methyl esters or amino acid amides as nucleophiles. Peptides may also be used as acyl components with the result that the nucleophile is incorporated in place of the C-terminal amino acid residue. i.e. a transpeptidation takes place.

The enzyme is easily saturated with amino acid amides indicating the formation of a complex between nucleophile and acyl-enzyme intermediate prior to deacylation. The apparent dissociation constant of this complex $\left(\mathrm{K}_{\mathrm{N}(\mathrm{appp})}\right)$ is approximately $1 \mathrm{~mm}$ with $\mathrm{H}-\mathrm{Lys}-\mathrm{NH}_{2}$ and $\mathrm{H}-\mathrm{Arg}-\mathrm{NH}_{2}$ while it is $13 \mathrm{~mm}$ with amino acid amides with uncharged side-chains. At saturation with these nucleophiles the fraction of aminolysis are $0.80-0.95$. However, saturation cannot be achieved with amino acids and amino acid esters as nucleophiles and the fractions of aminolysis are lower than with amino acid amides. The specificity of carboxypeptidase II renders it suitable for synthesis of peptide bonds where the acyl and/or the imine portion is donated by a basic amino acid residue.
\end{abstract}

\footnotetext{
Abbreviations: Bicine $=\mathrm{N}, \mathrm{N}$-bis (2-hydroxyethyl)glycine; $\mathrm{Bu}=$ butyl; $\mathrm{Bz}=\mathrm{N}$-benzoyl; EDTA $=$ ethylene diamine tetraacetic acid; FA = furylacryloyl; Hepes = N-2-hydroxyethylpiperazine-N'-2-ethanesulfonic acid; HPLC = high performance liquid chromatography; Mes $=2$-( $\mathrm{N}$-morpholino)ethane sulfonic acid; $\mathrm{PhGu}=$ phenyl guanidine hydrogencarbonate; $Z$ = carbobenzoxy. Other abbreviations of amino acids, amino acid derivatives and peptides are according to the guidelines of the IUPAC-IUB Commission on Biochemical Nomenclature. The binding site notations for the enzyme is that of SCHECHTER and BERGER (16). Accordingly, the binding site for the C-terminal amino acid residue of the substrate is denoted $S_{1}^{\prime}$ and those for the amino acid residues in the amino-terminal direction away from the scissile bond are denoted $S_{1}, S_{2}, \ldots ., S_{i}$. The substrate positions all denoted $P_{1}, P_{1}, P_{2}, \ldots . P_{1}$ in correspondence with the binding sites.
} 


\section{INTRODUCTION}

The serine carboxypeptidase from yeast, carboxypeptidase $\mathrm{Y}$, is an effective tool in enzymatic peptide synthesis because it catalyzes aminolysis of peptide esters with formation of new peptide bonds $(1,18,19,20)$ and transpeptidation reactions which exchange the C-terminal amino acid residues of existing peptides $(10,11)$. However, the yield of synthesis is variable, reflecting the side-chain specificity of the enzyme and consequently, the availability of other serine carboxypeptidases with different specificities is desirable.

Ion exchange chromatography of extracts from malted barley has indicated the presence of five different carboxypeptidases, termed carboxypeptidases I to V (14). Carboxypeptidases I and II have been purified $(3,9)$ and they are both inhibited by diisopropylfluorophosphate and hence, serine carboxypeptidases. It appears that these two enzymes are similar in terms of physical-chemical properties but different with respect to their specificities towards peptide substrates $(3,9)$. Carboxypeptidase I has been shown to catalyze the hydrolysis and aminolysis of peptide esters $(4,7)$ but it suffers from lack of stability at basic $\mathrm{pH}$ values (3) where peptide synthesis preferentially should be performed ( 7 , 18 ) and in addition, it is available only in rather small amounts (3). Carboxypeptidase II, on the other hand, is available in large amounts, it exhibits a better stability at basic $\mathrm{pH}$ values and a specificity which differs from that of carboxypeptidase $Y(9)$. In the present paper carboxypeptidase II has been studied with respect to its ability to synthesize peptide bonds.

\section{MATERIALS AND METHODS}

\subsection{Materials}

The following materials were prepared as previously described: malt carboxypeptidase II, FA-Phe-Phe-OH, and FA-Phe-Ala-OH (9); FAPhe-Gly-OH, FA-Phe- $\mathrm{NH}_{2}$, and FA-Phe-Gly$\mathrm{NH}_{2}$ (3); FA-Phe-Leu-OH, FA-Ala-OEt, FAPhe-OEt, FA-Phe-Val-NH ${ }_{2}$, FA-Ala-OBzl, and FA-Ala-OMe (8); Bz-Arg-OBu and Bz-ProOMe (4); Bz-Gly-OMe and Bz-Phe-OMe (1); Bz-Ile-OMe (2), Bz-Lys-Ala-OH (5). FA-ArgOMe was synthesized in the following manner:
3 mmol FA-N-hydroxysuccinimide ester was dissolved in $7 \mathrm{ml}$ dioxane and $7 \mathrm{ml}$ water containing $6 \mathrm{mmol} \mathrm{NaHCO}$ and $3 \mathrm{mmol} \mathrm{H}$ $\mathrm{Arg}-\mathrm{OMe} \cdot 2 \mathrm{HCl}$ was added. After 2 hours reaction the dioxane was evaporated and $\mathrm{pH}$ lowered to 4.0 by addition of $1 \mathrm{M}-\mathrm{HCl}$. After extraction with ethylacetate the aqueous phase, containing 90\% FA-Arg-OMe and 10\% FA-Arg-OH as judged by HPLC analysis, was lyophilized. This preparation was utilized without further purification since attempts to crystallize the substrate failed.

$\mathrm{H}$-Thr- $\mathrm{NH}_{2}$ was obtained from Carlsberg Biotechnology, Denmark; H-Arg- $\mathrm{NH}_{2} \cdot 2$ acetate from Senn Chemicals, Switzerland; H-Gly-OH and solvents from Merck, W. Germany; Bz-Val$\mathrm{OMe}, \mathrm{Bz}-\mathrm{His}-\mathrm{OMe}$ and Bz-Met-OMe from Vega-Fox, USA; H-Val-OH, H-Gly- $\mathrm{NH}_{2} \cdot \mathrm{HCl}$, $\mathrm{H}-\mathrm{Arg}-\mathrm{OH} \cdot \mathrm{HCl}, \mathrm{H}-\mathrm{Ser}-\mathrm{OH}, \mathrm{H}-\mathrm{Ser}-\mathrm{NH}_{2}$, Hepes, Mes, Bicine, Bz-Arg-OMe and Bz-ArgOEt from Sigma, USA. All other amino acids, amino acid derivatives, peptide and peptide ester substrates were from Bachem, Switzerland. Phenyl guanidine bicarbonate was obtained from EGA Chemie, W. Germany.

\subsection{Methods}

All enzymatic activities were determined spectrophotometrically at $254 \mathrm{~nm}$ for Bz-substrates and at $329-350 \mathrm{~nm}$ for FA-substrates using a Cary 219 spectrophotometer thermostated at $25{ }^{\circ} \mathrm{C}$. $\mathrm{k}_{\text {cat }}$ and $\mathrm{K}_{\mathrm{m}}$ values were graphically determined from Lineweaver-Burk plots. The $\mathrm{pH}$ profiles for the action of malt carboxypeptidase II was carried out in $25 \mathrm{~mm}$ buffer, $1 \mathrm{mM}$-EDTA. The following buffers were used: acetic acid, pH 3 - 5.8; Mes, pH 5.5 - 7; Hepes, pH 7 - 8; Bicine, pH 8 - 9 .

Aminolysis reactions $(1 \mathrm{ml})$ were carried out in a pH stat (18) in the presence of $5 \mathrm{mM}$-EDTA. pH did not exceed 8.5 since malt carboxypeptidase II is unstable at $\mathrm{pH}$ values above 8.7. Unless specifically stated, the reactions were allowed to proceed until $80-95 \%$ of the substrate had been consumed. At this stage aliquots were removed for determination of the reactant composition by HPLC, using equipment from Waters Associates, USA, and a $10 \mu$ Radial-Pak C-18 reverse phase column. The following eluant system was 


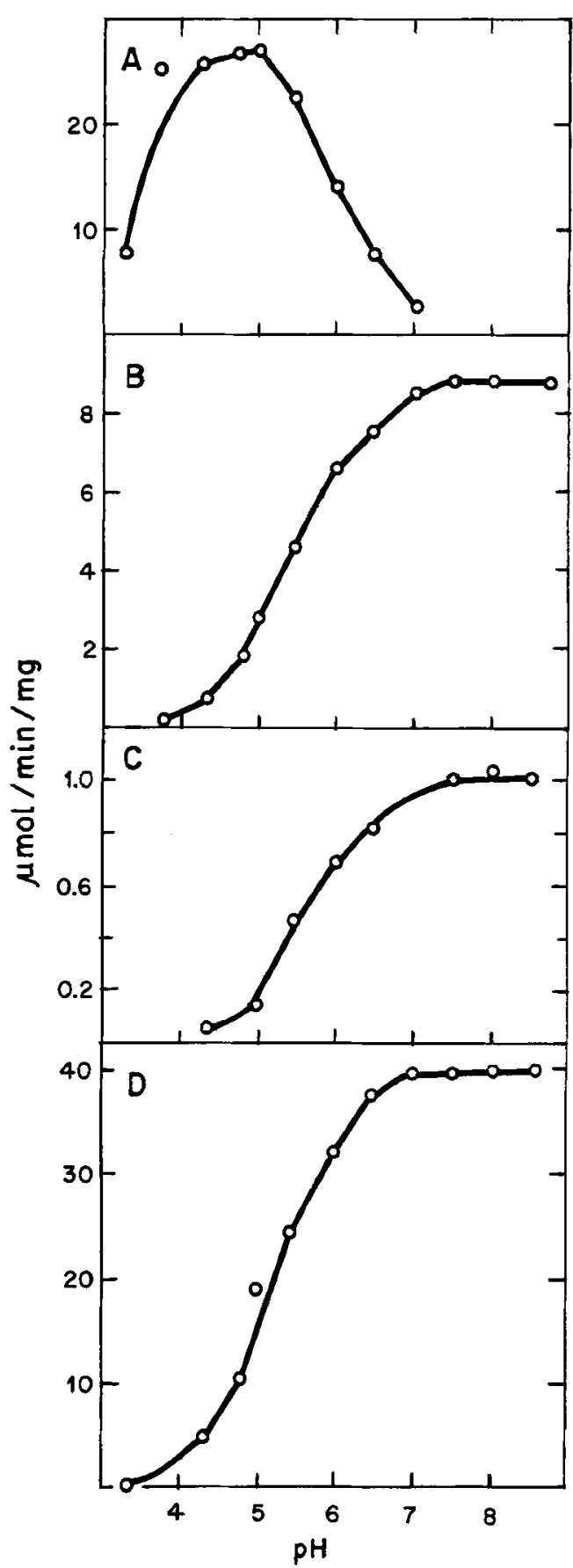

Figure 1. pH profiles for the malt carboxypeptidase II catalyzed hydrolysis of FA-Phe-Gly-OH (A), FA-

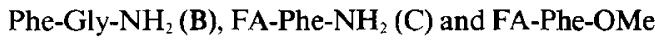
(D). The assays were performed at $0.2 \mathrm{~mm}$ substrate in $25 \mathrm{~mm}$ buffer, $1 \mathrm{~mm}$-EDTA, $1.0 \mathrm{M}-\mathrm{NaCl}, 2.5 \%$ $\mathrm{CH}_{3} \mathrm{OH}$. The buffers employed are listed in section 2.2 .

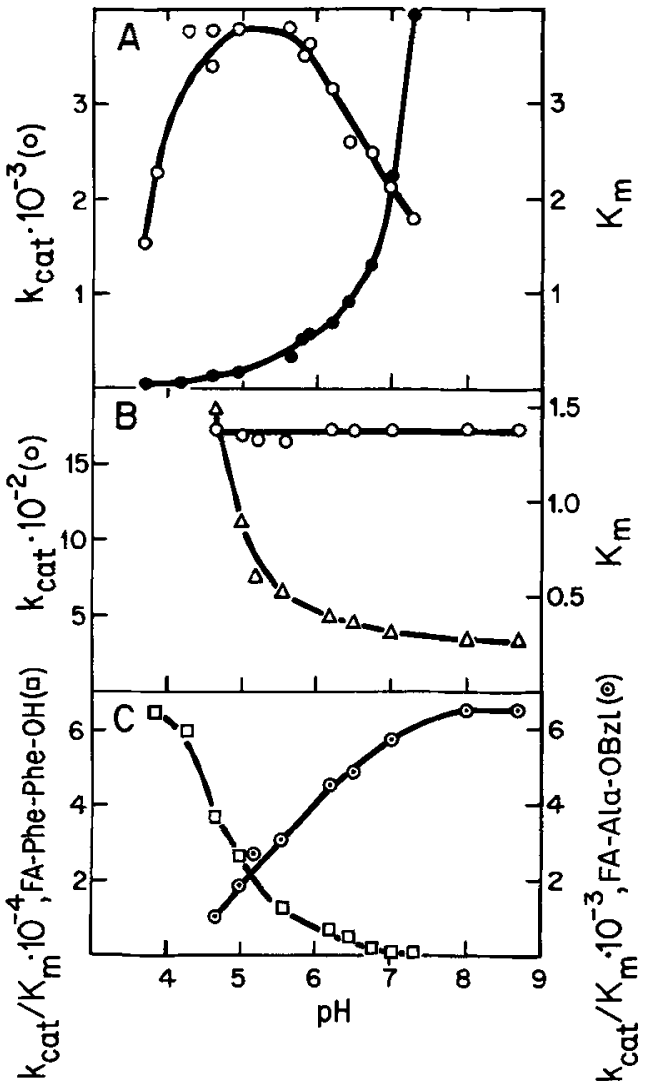

Figure 2. The influence of $\mathrm{pH}$ on the kinetic parameters for the carboxypeptidase II catalyzed hydrolysis of FA-Phe-Phe-OH (A) and FA-Ala-OBzl (B). Panel $C$ shows the $p H$ dependence of $k_{c a} / K_{m}$ for the two substrates. The assays were performed in $25 \mathrm{~mm}$ buffer, 1 mM-EDTA. With FA-Ala-OBzl the assay mixture contained $2.5 \% \mathrm{CH}_{3} \mathrm{OH}$. The buffers employed are listed in section 2.2 .

used: 50 mM-triethyl ammonium phosphate, $\mathrm{pH} 3.0$ (A-buffer) and $50 \mathrm{mM}$-triethyl ammonium phosphate, pH 3.0 in $50 \% \mathrm{CH}_{3} \mathrm{CN}$ (Bbuffer) employing various linear and concave gradients. All separations were carried out at room temperature and monitored at $254 \mathrm{~nm}$. The per cent composition of the reaction mixture was estimated directly from the integrated peak areas since all components had the Bz- or Z-group as dominant chromophore. Aminolysis and hydrolysis products were collected and identified by amino acid analysis. The fraction of 
Table I. Hydrolysis of $\mathrm{Bz}-\mathrm{X}-\mathrm{OMe}$ substrates $(\mathrm{X}=$ amino acid residue) with malt carboxypeptidases $\mathrm{I}$ and $\mathrm{II}$

\begin{tabular}{lcc}
\hline Substrate & \multicolumn{2}{c}{$\mathbf{k}_{\mathrm{cat}} / \mathrm{K}_{\mathrm{nt}}\left(\mathrm{min}^{-1} \cdot \mathrm{mm}^{-1}\right)$} \\
\hline Bz-Gly-OMe & Carboxypeptidase II & Carboxypeptidase I \\
Bz-Ala-OMe & $<5$ & $<5$ \\
Bz-Val-OMe & 19 & 370 \\
Bz-Ile-OMe & 7.1 & 22 \\
Bz-Leu-OMe & 7.5 & 17 \\
Bz-Met-OMe & 310 & 420 \\
Bz-Phe-OMe & 160 & 1200 \\
Bz-Pro-OMe & 5700 & 14600 \\
Bz-Asp-OMe & $<5$ & $<5$ \\
Bz-Lys-OMe & $<5$ & $<5$ \\
Bz-Arg-OMe & 2200 & 18300 \\
Bz-His-OMe & 950 & 25300 \\
Bz-Thr-OMe & 76 & 5600 \\
\hline
\end{tabular}

Assay conditions: $0.5 \mathrm{~mm}$ substrate, $2.5 \% \mathrm{CH}_{3} \mathrm{OH}, 25 \mathrm{~mm}$-Hepes, 1 mM-EDTA pH $8.0,25^{\circ} \mathrm{C}$. With Bz-Lys-OMe, $\mathrm{Bz}-\mathrm{Arg}$-OMe and $\mathrm{Bz}-\mathrm{His}-\mathrm{OMe} \mathrm{CH}_{3} \mathrm{OH}$ was omitted. The rate of hydrolysis was measured spectrophotometrically at $254 \mathrm{~nm}$ and followed to more than $95 \%$ completion. From the progression curves $k_{c a} / K_{m}$ values were determined utilizing the integrated form of the Michaelis-Menten equation (17). The values were based on the molecular weights of the monomer $(60,000)$. The values for malt carboxypeptidase I were taken from ref. 4.

aminolysis was expresssed as the ratio between the formed aminolysis product and the sum of all products being formed, i.e. unconsumed substrate was disregarded in the calculations.

\section{RESULTS}

\subsection{Enzymatic properties of malt carboxypepti-} dase II

The $\mathrm{pH}$ profiles for the peptidase, esterase, amidase and peptidyl amino acid amide hydrolase activities of malt carboxypeptidase II towards FA-Phe ${ }^{\downarrow}$ Gly-OH, FA-Phe ${ }^{\ddagger} \mathrm{OMe}$, FAPhe $-\mathrm{NH}_{2}$ and FA-Phe- ${ }^{\downarrow}$ Gly- $\mathrm{NH}_{2}$, respectively, are shown in Figure 1. The stability of the enzyme (9) allowed the enzymatic activity to be studied in the $\mathrm{pH}$ range $3.4-8.7$. The $\mathrm{pH}$ profiles reflect $k_{c a t} / K_{m}$ since the hydrolysis reactions were carried out at a substrate concentration below $\mathrm{K}_{\mathrm{m}}$. The hydrolysis of FA-Phe-OMe, FA-Phe$\mathrm{NH}_{2}$ and FA-Phe-Gly- $\mathrm{NH}_{2}$ is optimal at $\mathrm{pH}>7$, and apparently dependent on deprotonation of a group with a $\mathrm{pK}_{\mathrm{a}}$ of $5.2-5.6$. In contrast, the hydrolysis of the peptide substrate FA-Phe-Gly$\mathrm{OH}$ is optimal at $\mathrm{pH}$ 4.7. The difference in $\mathrm{pH}$

Table II. The influence of the size of the alcohol leaving group on the kinetic parameters of malt carboxypeptidase II catalyzed ester hydrolysis.

\begin{tabular}{lllc}
\hline Substrate & $\begin{array}{l}\mathrm{K}_{\mathrm{m}} \\
(\mathrm{mM})\end{array}$ & $\begin{array}{l}\mathbf{k}_{\mathrm{cal}} \\
\left(\mathrm{min}^{-1}\right)\end{array}$ & $\begin{array}{l}\mathbf{k}_{\mathrm{cal}} / \mathrm{K}_{\mathrm{m}} \\
\left(\mathrm{min}^{-1} \cdot \mathrm{mM}^{-1}\right)\end{array}$ \\
\hline Bz-Arg-OMe & 0.30 & 350 & 1200 \\
Bz-Arg-OEt & 0.13 & 110 & 860 \\
Bz-Arg-OBu & 0.037 & 770 & 21000 \\
\hline
\end{tabular}

The substrates were assayed in $25 \mathrm{~mm}$-Hepes, $1 \mathrm{~mm}$-EDTA, pH 8.0 at $25^{\circ} \mathrm{C}$. 


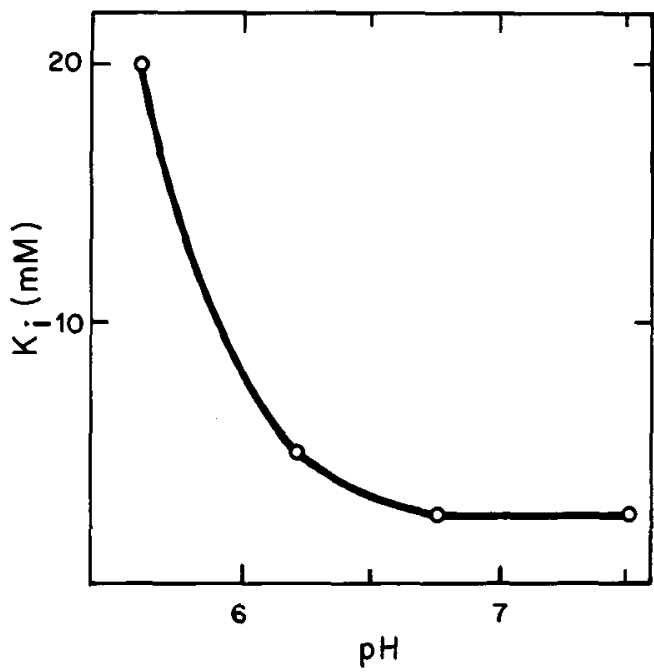

Figure 3. The competitive inhibition of $\mathrm{PhGu}$ on the hydrolysis of FA-Ala-Lys-OH. The influence of $\mathrm{pH}$ on $\mathrm{K}_{\mathrm{i}}$. The inhibition of $\mathrm{PhGu}$ was studied in $25 \mathrm{~mm}$ buffer, 1 mM-EDTA. The buffers employed are listed in section 2.2 .

profile between ester and peptide hydrolysis was investigated in further detail with the substrates FA-Ala-OBzl and FA-Phe- ${ }^{\downarrow}$ Phe-OH. $k_{\text {cat }}$ for the hydrolysis of FA-Phe-Phe-OH (Figure 2A) increases with $\mathrm{pH}$ and reaches a maximum at $\mathrm{pH}$ 4.6 and again declines above $\mathrm{pH}$ 6. For FA-Ala $\downarrow$ OBzl $k_{\text {cat }}$ is constant in the $\mathrm{pH}$ range 4.6-8.7. On the other hand, $\mathrm{K}_{\mathrm{m}}$ increases with $\mathrm{pH}$ for the hydrolysis of FA-Phe ${ }^{\downarrow}$ Phe-OH (Figure 2A) while it decreases with $\mathrm{pH}$ for the hydrolysis of FA-Ala $\_$OBzl (Figure 2B). These different effects of $\mathrm{pH}$ on $\mathrm{K}_{\mathrm{m}}$ explain why $\mathrm{k}_{\mathrm{cal}} / \mathrm{K}_{\mathrm{m}}$ for the hydrolysis of FA-Phe-Phe-OH is optimal below pH 4 while for FA-Ala-OBzl it is optimal above $\mathrm{pH}$ 7.5 (Figure 2C). High $K_{m}$ values precluded determinations at $\mathrm{pH}$ values above 7.3 for FAPhe-Phe-OH and below 4.6 for FA-Ala-OBzl.

The specificity of carboxypeptidase II with respect to the $P_{1}$ position of peptide substrates has previously been determined (9) and the specificity with respect to the $P_{1}$ position of ester substrates was investigated at $\mathrm{pH} 8.0$ using a series of substrates with the general formula $\mathrm{Bz}-\mathrm{X} \downarrow^{\downarrow} \mathrm{OMe}$ (Table I). The highest $\mathbf{k}_{\mathrm{ca}} / \mathrm{K}_{\mathrm{m}}$ is obtained for Bz-Phe-OMe and this value is 15 -

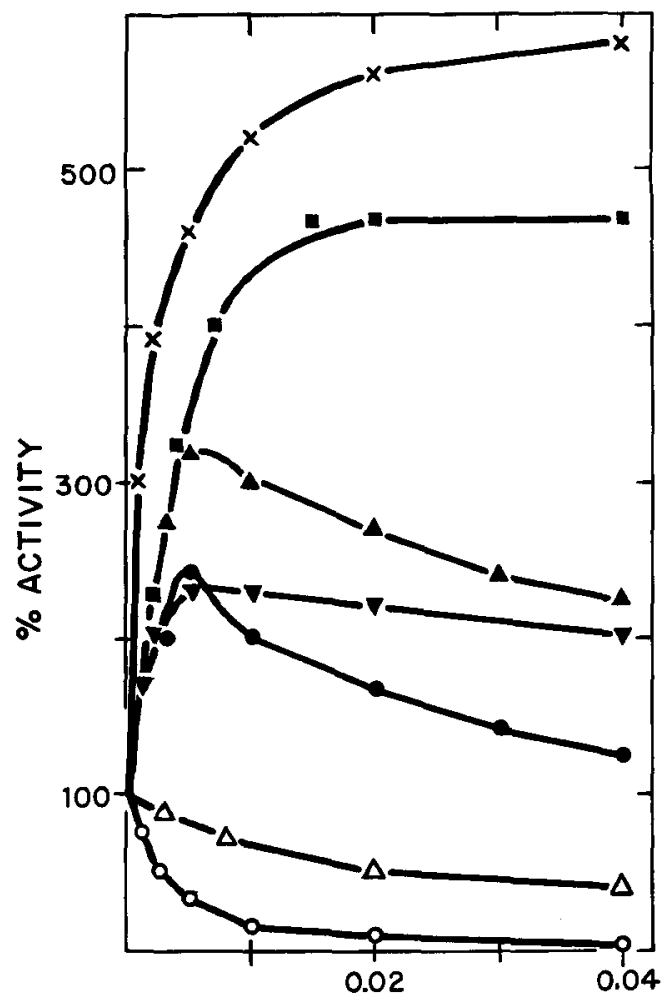

[PhGu], M

Figure 4. The influence of PhGu on the activities of malt carboxypeptidase. The assays with FA-Arg $\mathrm{OMe}(\Delta)$, FA-Phe-OMe (X), FA-Phe- $\mathrm{NH}_{2}(\mathbf{\square})$ and FA-Phe-Gly- $\mathrm{NH}_{2}(\mathbf{\nabla})$ were performed in $0.05 \mathrm{M}$ Hepes, $1 \mathrm{~mm}$-EDTA, pH 7.5 and those with FA-AlaLys-OH (O), FA-Phe-Gly-OH (A) and FA-Phe-Phe$\mathrm{OH}(\bullet)$ were performed in $0.05 \mathrm{~mm}-\mathrm{Mes}, 1 \mathrm{~mm}-$ EDTA, pH 6.75. A substrate concentration of $0.2 \mathrm{mM}$ was used and the assay mixture contained $2.5 \%$ $\mathrm{CH}_{3} \mathrm{OH}$ except with FA-Ala-Lys-OH and FA-Arg OMe. The indicated concentrations of $\mathrm{PhGu}$ were included in the assays.

30 times higher than the value obtained with substrates with an aliphatic side-chain with an unbranched $\boldsymbol{\beta}$ carbon, i.e. Leu and Met. The substrates with a branched $\beta$ carbon, i.e. Val and Ile, are hydrolysed with very low rates, and those with Pro, Gly, Thr and Asp are hydrolysed with negligible rates. The substrates where the $\mathrm{X}$ position is occupied by an amino acid residue with a positively charged side-chain, i.e. Arg and 
Table III. The effects of $\mathrm{PhGu}$ and $\mathrm{NaCl}$ on the kinetic parameters for the malt carboxypeptidase II catalyzed hydrolysis reactions.

\begin{tabular}{|c|c|c|c|c|}
\hline \multirow[b]{2}{*}{ Substrate } & & \multicolumn{3}{|c|}{ Effector } \\
\hline & & 0 & $20 \mathrm{mM}-\mathrm{PhGu}$ & $1 \mathrm{M}-\mathrm{NaCl}$ \\
\hline \multirow[t]{4}{*}{ FA-Phe-OMe } & $\mathrm{k}_{\mathrm{cat}}$ & 5600 & 9500 & 5700 \\
\hline & $\mathbf{K}_{\mathrm{m}}$ & 0.80 & 0.12 & 0.24 \\
\hline & $\mathbf{k}_{\text {cat }} / \mathbf{K}_{\mathrm{m}}$ & 7000 & 79000 & 24000 \\
\hline & $\% \mathrm{k}_{\text {cal }} / \mathrm{K}_{\mathrm{m}}$ & & 1100 & 340 \\
\hline \multirow[t]{4}{*}{ FA-Phe-OEt ${ }^{a}$} & $\mathbf{k}_{\text {cat }}$ & 5200 & 8200 & 5400 \\
\hline & $\mathrm{K}_{\mathrm{m}}$ & 0.75 & 0.18 & 0.26 \\
\hline & $\mathbf{k}_{\mathrm{ca} a} / \mathrm{K}_{\mathrm{m}}$ & 6900 & 46000 & 21000 \\
\hline & $\% \mathrm{k}_{\text {cal }} / \mathrm{K}_{\mathrm{m}}$ & & 670 & 300 \\
\hline \multirow[t]{4}{*}{ FA-Ala-OEt } & $\mathrm{k}_{\mathrm{cat}}$ & 140 & 2200 & 220 \\
\hline & $\mathrm{K}_{\mathrm{m}}$ & 4.3 & 4.3 & 2.1 \\
\hline & $\mathbf{k}_{\mathrm{cat}} / \mathrm{K}_{\mathrm{m}}$ & 33 & 510 & 105 \\
\hline & $\% \mathrm{k}_{\mathrm{cat}} / \mathrm{K}_{\mathrm{m}}$ & & 1500 & 320 \\
\hline \multirow[t]{4}{*}{ FA-Ala-OBzl ${ }^{a}$} & $\mathbf{k}_{\mathrm{cal}}$ & 1600 & 2800 & 1600 \\
\hline & $\mathrm{K}_{\mathrm{m}}$ & 0.36 & 0.13 & 0.13 \\
\hline & $\mathbf{k}_{\mathrm{ca} /} / \mathrm{K}_{\mathrm{m}}$ & 4400 & 22000 & 12000 \\
\hline & $\% \mathbf{k}_{\mathrm{cat}} / \mathbf{K}_{\mathrm{m}}$ & & 500 & 270 \\
\hline \multirow[t]{4}{*}{ FA-Arg-OMe } & $\mathbf{k}_{\text {cat }}$ & 180 & 230 & 430 \\
\hline & $\mathbf{K}_{\mathrm{m}}$ & 0.19 & 0.77 & 2.7 \\
\hline & $\mathbf{k}_{\text {cat }} / \mathrm{K}_{\mathrm{m}}$ & 950 & 300 & 160 \\
\hline & $\% \mathrm{k}_{\mathrm{ca} a} / \mathrm{K}_{\mathrm{m}}$ & & 32 & 17 \\
\hline \multirow[t]{4}{*}{ FA-Phe-Phe-OH ${ }^{b /}$} & $\mathrm{k}_{\mathrm{cat}}$ & 3500 & 1100 & 2000 \\
\hline & $\mathbf{K}_{\mathbf{m}}$ & 2.8 & 0.56 & 0.83 \\
\hline & $\mathrm{k}_{\mathrm{cat}} / \mathrm{K}_{\mathrm{m}}$ & 1300 & 2000 & 2400 \\
\hline & $\% \mathrm{k}_{\mathrm{cat}} / \mathrm{K}_{\mathrm{m}}$ & & 150 & 180 \\
\hline \multirow[t]{4}{*}{ FA-Ala-Lys-OH ${ }^{b . c)}$} & $\mathrm{k}_{\mathrm{cat}}$ & 17100 & $17100^{\mathrm{c})}$ & 9600 \\
\hline & $\mathbf{K}_{\mathrm{m}}$ & 0.53 & $1.4^{\mathrm{c})}$ & 1.6 \\
\hline & $\mathrm{k}_{\mathrm{cat}} / \mathbf{K}_{\mathrm{m}}$ & 32000 & $12000^{c \prime}$ & 6000 \\
\hline & $\% \mathrm{k}_{\mathrm{caa}} / \mathrm{K}_{\mathrm{m}}$ & & 38 & 19 \\
\hline
\end{tabular}

$\mathrm{k}_{\mathrm{cat}}$ values are in $\min ^{-1}, \mathrm{~K}_{\mathrm{m}}$ values in $\mathrm{mM}$ and $\mathrm{k}_{\mathrm{ca}} / \mathrm{K}_{\mathrm{m}}$ in $\min ^{-1} \cdot \mathrm{mM}^{-1}$.

a) The substrates were assayed in $0.05 \mathrm{M}$-Hepes, $1 \mathrm{mM}$-EDTA, pH 7.5.

b) The substrates were assayed in $0.05 \mathrm{M}$-Mes, $1 \mathrm{mM}$-EDTA, pH 6.75.

c) The assays were carried out in only $5 \mathrm{~mm}-\mathrm{PhGu}$.

Lys, are hydrolysed with relatively high rates. The concentrations of Bz-Arg $-\mathrm{OMe}, \mathrm{Bz}-\mathrm{Lys}-$ OMe and Bz-Phe-OMe could be varied sufficiently to allow determination of $k_{c a t}$ and $K_{m}$ from linear Lineweaver-Burk plots. The values were for Bz-Phe-OMe: $\mathrm{k}_{\text {cat }}=5600 \mathrm{~min}^{-1}, \mathrm{~K}_{\mathrm{m}}=1.0$ $\mathrm{mM}$; for Bz-Arg $\stackrel{\downarrow}{ } \mathrm{OMe}: \mathrm{k}_{\text {cat }}=350 \mathrm{~min}^{-1}, \mathrm{~K}_{\mathrm{m}}=0.30$
$\mathrm{mM}$; and for Bz-Lys $\downarrow$ OMe: $\mathrm{k}_{\mathrm{cat}}=850 \mathrm{~min}^{-1}, \mathrm{~K}_{\mathrm{m}}=$ $0.30 \mathrm{~mm}$.

The influence of the size of the alcohol leaving group of ester substrates was investigated using three Bz-Arg-OX substrates ( $\mathrm{X}=\mathrm{Me}, \mathrm{Et}, \mathrm{Bu}$ ) (Table II). It is seen that $\mathrm{K}_{\mathrm{m}}$ decreases with increasing size/hydrophobicity of the leaving 


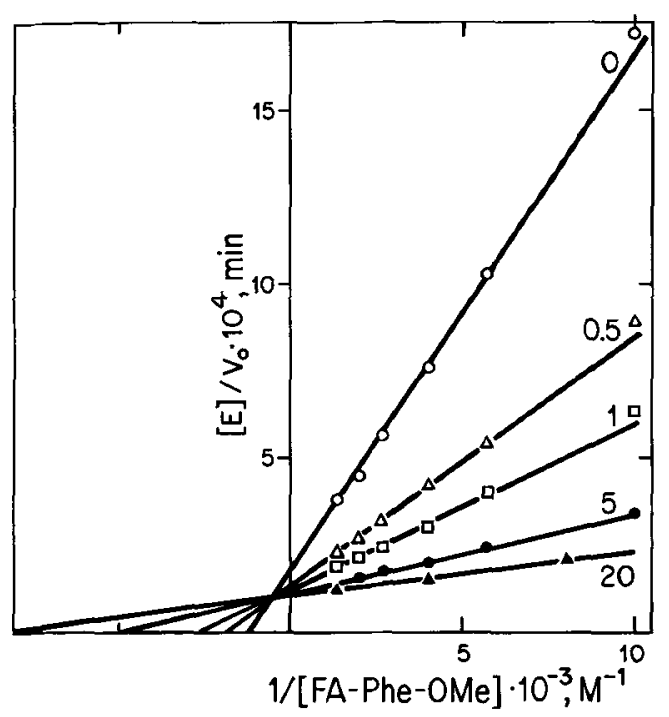

Figure 5. Lineweaver-Burk plots of the hydrolysis of FA-Phe-OMe in $0.05 \mathrm{M}$-Hepes, $1 \mathrm{mM}$-EDTA, $2.5 \%$ $\mathrm{CH}_{3} \mathrm{OH}, \mathrm{pH} 7.5$ containing variable concentrations of $\mathrm{PhGu}$. The numbers indicate the concentrations of $\mathrm{PhGu}$ in $\mathrm{mm}$.

group. $\mathrm{k}_{\text {cat }}$ also varies with the size of the leaving group in the following manner: Bz-Arg-OBu > $\mathrm{Bz}-\mathrm{Arg} \_\mathrm{OMe}>\mathrm{Bz}-\mathrm{Arg} \_\mathrm{OEt}$.

\subsection{Influence of $\mathrm{PhGu}$ on malt carboxy- peptidase II}

$\mathrm{PhGu}$ has previously been shown to have a pronounced influence on the enzymatic properties of malt carboxypeptidase I (4) and hence, it was tested whether malt carboxypeptidase II also is affected by this substance. Lineweaver-Burk plots at different concentrations of $\mathrm{PhGu}$ indicates that it acts as a competitive inhibitor with respect to the hydrolysis of FA-Ala $-\mathrm{Lys}-\mathrm{OH}$ and $\mathrm{K}_{\mathrm{i}}$ decreases with $\mathrm{pH}$ with the lowest values being observed in the pH range 6.75 to 7.5 (see Figure 3). For this reason the influence of $\mathrm{PhGu}$ on the ability of carboxypeptidase II to hydrolyse peptide substrates was studied at $\mathrm{pH} 6.75$ in spite of the much more acidic $\mathrm{pH}$ optimum of its peptidase activity while the influence of $\mathrm{PhGu}$ on the hydrolysis of ester and amide substrates was studied at $\mathrm{pH} 7.5$, i.e. the optimum of these activities. PhGu decreases rates of hydrolysis of an ester substrate containing a basic amino acid residue in the $P_{1}$ position, i.e. FA-Arg $\=M$, and a peptide substrate with a basic amino acid residue in the $\mathrm{P}_{1}$ position i.e. FA-Ala-Lys-OH (Figure 4, open symbols). In contrast, $\mathrm{PhGu}$ increases the rates of hydrolysis of the uncharged substrates FA-Phe $\downarrow$ OMe and FA-Phe $=\mathrm{NH}_{2}$ until the activities reach constant levels indicating that the enzyme becomes saturated with this substance (Figure 4, closed symbols). The rates of hydrolysis of peptide and peptide amide substrates where both the $P_{1}$ and $P_{1}^{\prime}$ positions are occupied by uncharged amino acid residues are also increased by the addition of PhGu but at concentrations above $5 \mathrm{mM}$ the rates decrease (Figure 4).

The kinetic parameters for the hydrolysis of a series of substrates in the absence and in the presence of $20 \mathrm{mM}-\mathrm{PhGu}$ (Table III) confirm that the influence of $\mathrm{PhGu}$ is dependent on the substrate: with FA-Phe-OMe, FA-Phe-OEt, and FA-Ala $\downarrow$ OBzl $K_{m}$ is reduced and $k_{\text {cat }}$ is increased; with FA-Ala-OEt $\mathbf{k}_{\text {cat }}$ is drastically increased while $\mathrm{K}_{\mathrm{m}}$ is unchanged; with FA-Arg-OMe both $k_{\text {cat }}$ and $K_{m}$ increase and with FA-Phe-Phe-OH both $\mathrm{k}_{\mathrm{cat}}$ and $\mathrm{K}_{\mathrm{m}}$ decrease. These effects of $\mathrm{PhGu}$ were studied in further detail by determination of the kinetic parameters for these substrates at different concentrations of PhGu. As an example, the Lineweaver-Burk plots obtained for FA-Phe-OMe are shown in Figure 5. The effects of PhGu can be described in terms of a nonessential activator/mixed inhibitor mechanism, shown in its general form in Scheme 1 , as described by SEGEL (17). $\alpha$ and $\beta$ are the factors by which $K_{s}$ and $k_{\text {cat }}$ change when $A$ occupies the enzyme and $K_{A}$ is the dissociation constant of the EA complex. If rapid equilibrium assumptions are applied to Scheme 1 values for $\alpha, \beta$ and $K_{\mathrm{A}}$ can be obtained from a plot of $\mathrm{K}_{\mathrm{m}}^{\circ} / \Delta \mathrm{K}_{\mathrm{m}}$ and $\mathrm{k}_{\mathrm{ca} 2}^{\mathrm{o}} / \Delta \mathrm{k}_{\mathrm{cat}}$ versus $1 /[\mathrm{PhGu}]$ as described by SEGEL (17) and modified by ROHRBACH et al. (15). The

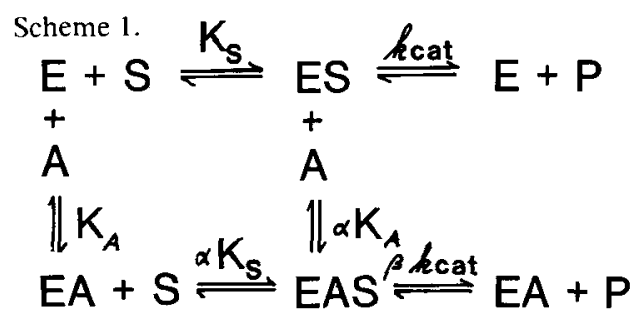




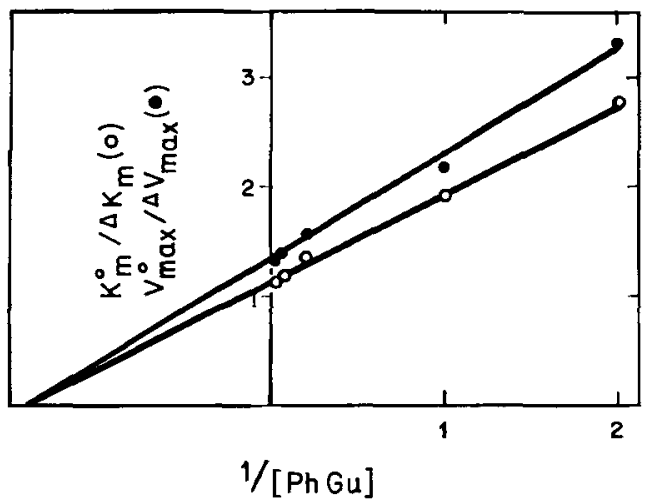

Figure 6. Replot of $\mathrm{V}_{\max }^{\circ} / \Delta \mathrm{V}_{\max }$ and $\mathrm{K}_{\mathrm{m}}^{\circ} / \Delta \mathrm{K}_{\mathrm{m}}$ versus 1/[FA-Phe-OMe] as described in ref. 15. The intersection of both lines with the $\mathrm{X}$-axis is equal to $-1 / \alpha \mathrm{K}_{\mathrm{A}}$ while the intersection of $V_{\text {max }}^{\circ} / \Delta V_{\text {max }}$ with the $Y$-axis equals $1 /(\beta-1)$ and the intersection of $K_{m}^{\circ} / \Delta K_{m}$ equals $1 /(1-\alpha)$.

plot obtained for FA-Phe-OMe is shown in Figure 6. The values for $\alpha, \beta$ and $K_{A}$ obtained in this manner for the substrates used in Table III are listed in Table IV. It is seen that $\mathrm{K}_{\mathrm{A}}$ varies between 6 and $8 \mathrm{mM}$ when determined by assays of esterase activity and that $\beta$ with these substrates is higher than unity, and highest for FA-Ala-OEt with a value of 26 . The $\alpha$ values are below 1 for FA-Phe-OMe, FA-Phe $\downarrow$ OEt and FA-Ala-OBzl, 1.0 for FA-Ala $\_$OEt and impor-

Table IV. Binding of PhGu to malt carboxypeptidase II: the influence of the substrate structure on the $\alpha$, $\beta$ and $K_{A}$ values.

\begin{tabular}{llcl}
\hline Substrate & $\boldsymbol{\alpha}$ & $\boldsymbol{\beta}$ & $\begin{array}{l}\mathrm{K}_{\mathrm{A}} \text { or } \mathbf{K}_{\mathrm{i}} \\
(\mathrm{mM})\end{array}$ \\
\hline FA-Phe-OMe $^{\text {a) }}$ & 0.12 & 1.8 & 5.8 \\
FA-Phe-OEt $^{\text {a) }}$ & 0.17 & 1.8 & 6.3 \\
FA-Ala-OEt $^{\text {a) }}$ & 1.0 & 26 & 8 \\
FA-Ala-OBzl $^{\text {a) }}$ & 0.31 & 1.9 & 7.0 \\
FA-Arg-OMe $^{\text {a) }}$ & 9 & 4 & 8 \\
FA-Ala-Lys-OH $^{\text {by }}$ & $\infty$ & 1.0 & 3 \\
FA-Phe-Phe-OH $^{\text {by }}$ & complex, see text &
\end{tabular}

The $\alpha, \beta$ and $K_{A}$ values (see Scheme l) were calculated on the basis of $k_{\text {cal }}$ and $K_{m}$ values, determined at a minimum of five different concentrations of PhGu. a) The hydrolysis was carried out in $0.05 \mathrm{M}-\mathrm{Hepes}$, 1 mM-EDTA, pH 7.5. b) hydrolysis carried out in 0.05 M-Mes, 1 mM-EDTA, pH 6.75.

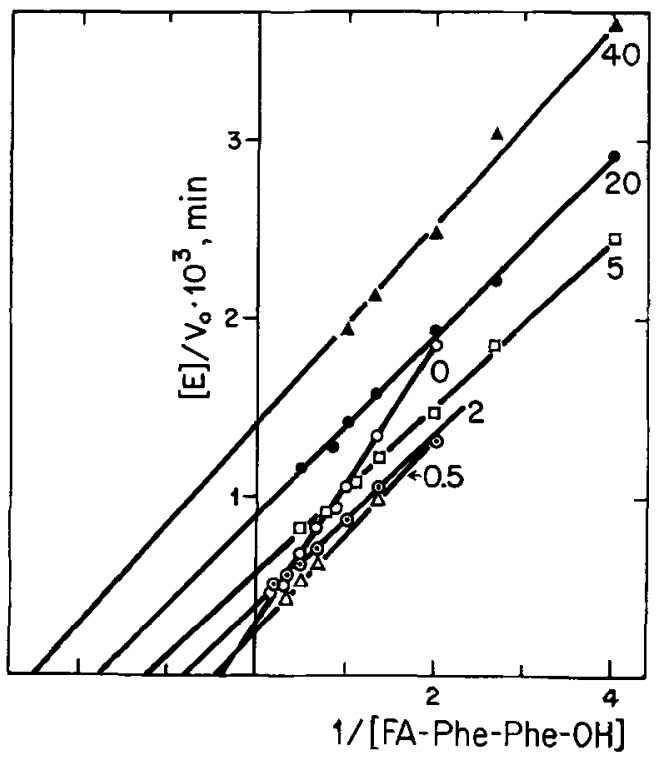

Figure 7. Lineweaver-Burk plots of the hydrolysis of FA-Phe-Phe-OH in $0.05 \mathrm{M}$-Mes, $1 \mathrm{~mm}$-EDTA, $2.5 \%$ $\mathrm{CH}_{3} \mathrm{OH}, \mathbf{p H} 6.5$ containing variable concentrations of PhGu. The numbers indicate the concentrations of $\mathrm{PhGu}$ in $\mathrm{mm}$.

tantly, significantly higher than 1 for the charged ester substrate FA-Arg $\stackrel{\downarrow}{ }$ OMe. For FA-Ala $\_$Lys$\mathrm{OH}$ the competitive nature of the inhibition of $\mathrm{PhGu}$ dictates that $\alpha$ is infinity while $\beta$ is 1 . With FA-Phe-Phe-OH as substrate the influence of $\mathrm{PhGu}$ is rather complex. Up to $0.5 \mathrm{~mm}-\mathrm{PhGu}$ the Lineweaver-Burk plots pivot clockwise (Figure 7) corresponding to an increase in $\mathrm{k}_{\text {cat }}$ and a decrease in $\mathrm{K}_{\mathrm{m}}$ similar to the observations with FA-Phe-OMe. However, further increases in the concentration of $\mathrm{PhGu}$ produce a series of parallel Lineweaver-Burk plots corresponding to reductions in both $\mathrm{k}_{\mathrm{cat}}$ and $\mathrm{K}_{\mathrm{m}}$ indicating that $\mathrm{PhGu}$ at high concentrations exhibits uncompetitive inhibition. For this mode of inhibition a $\mathrm{K}_{\mathrm{i}}$ of approximately $20 \mathrm{mM}$ was determined from a plot of $1 / \mathrm{K}_{\mathrm{m}}$ and $1 / \mathrm{k}_{\mathrm{cat}}$ versus [PhGu] as described by SEGEL (17) (plot not shown).

\subsection{The influence of added salt on malt carboxy- peptidase II catalyzed hydrolysis}

The malt carboxypeptidase II catalysed hydrolysis of ester and peptide substrates contain- 


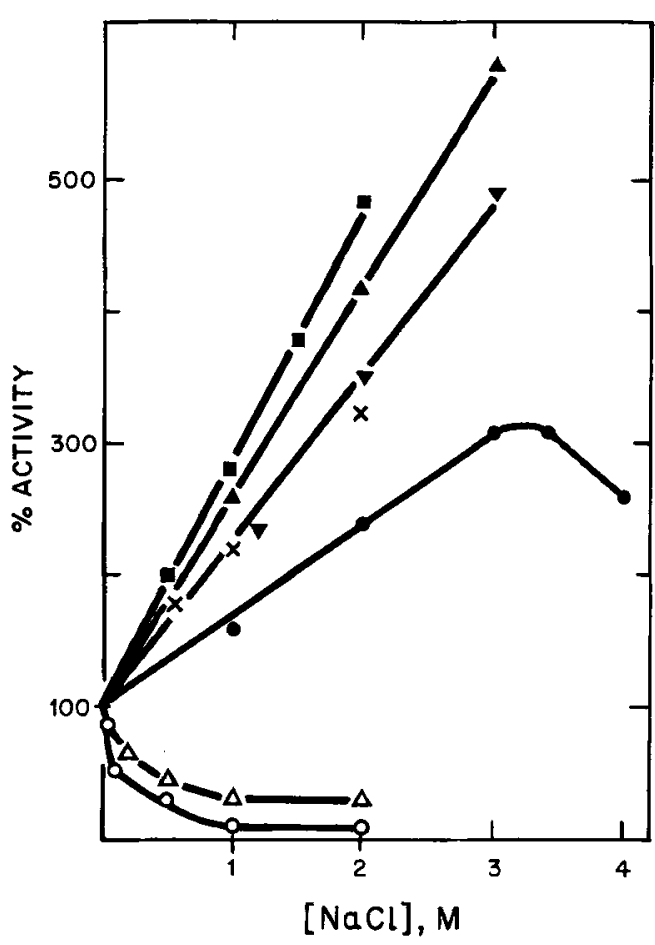

Figure 8 . The influence of $\mathrm{NaCl}$ on the activities of malt carboxypeptidase. The activities were assayed as described in Figure 4.

ing basic amino acid residues on the $\mathbf{P}_{1}$ or $\mathbf{P}_{1}^{\prime}$ position, i.e. FA-Arg $\_$OMe and FA-Ala $\_$Lys$\mathrm{OH}$, are adversely affected by the addition of $\mathrm{NaCl}$ to the assay medium (Figure 8, open symbols). With substrates containing uncharged amino acid residues on these positions $\mathrm{NaCl}$ has the opposite effect: the rates of hydrolysis of FA-Phe-OMe, FA-Phe- $\mathrm{NH}_{2}$, FA-Phe-Gly- $\mathrm{NH}_{2}$, and FA-Phe-Gly-OH increase with the concentration of $\mathrm{NaCl}$ (Figure 8, closed symbols). This is also observed with FA-Phe ${ }^{\downarrow} \mathrm{Phe}-\mathrm{OH}$ as substrate up to $3 \mathrm{M}-\mathrm{NaCl}$; at higher concentrations a reduction in the rate of hydrolysis is observed (Figure 8, closed symbols). For hydrophobic substrates the solubility decreases with ionic strength. However, at $1 \mathrm{M}-\mathrm{NaCl}$ the influence of $\mathrm{NaCl}$ on the kinetic parameters for the hydrolysis of a series of substrates could be compared (Table III). For the hydrophobic substrates, i.e. FA-Phe $\_$OMe and FA-Phe $\_$OEt, FA-Ala $\_$OEt, FA-Ala $\_$OBzl and FA-Phe $\downarrow$ Phe-OH $\mathrm{K}_{\mathrm{m}}$ decreases while it increases for FA-Ala-Lys-OH and
FA-Arg-OMe, containing positively charged groups. $\mathrm{k}_{\mathrm{car}}$ remains constant or is slightly increased for all ester substrates while it is decreased for the peptide substrates.

These effects of $\mathrm{NaCl}$ were studied by determination of the kinetic parameters for each substrate at different concentrations of $\mathrm{NaCl}$ and analyzing the results in terms of the general scheme for non-essential activation and mixed type inhibition as described in section 3.2. With the hydrophobic ester substrates, i.e. FA-Phe OMe, FA-Phe-OEt, FA-Ala-OBzl and FA-Ala $O E t$, the values for $\alpha$ are around 0.05 and $\beta$ varies between 1.0 and 2.5 (Table V). With FA-Arg $\downarrow$ OMe and FA-Ala-Lys-OH the values for $\alpha$ are higher than unity, i.e. 50 and 2 , respectively, and the values for $\beta$ are 4 and 0.5 , respectively. Thus, the influence of $\mathrm{NaCl}$ on the hydrolysis of substrates containing positively charged amino acid residues differs from that on those containing uncharged amino acid residues. This is also apparent from the widely different $K_{4}$ values observed with these two groups of substrates: $0.05 \mathrm{M}$ and $0.09 \mathrm{M}$ with FA-Arg $\_$OMe and FA-Ala-Lys-OH, respectively, and values ranging from $1.3 \mathrm{M}$ to one exceeding $20 \mathrm{M}$ with the hydrophobic substrates. The influence of $\mathrm{Na}_{2} \mathrm{SO}_{\downarrow}$ on the hydrolysis of FA-Phe-OMe has also been studied. The values for $\alpha$ and $\beta$ are identical to those obtained with $\mathrm{NaCl}$, i.e. 0.06

Table $\mathrm{V}$. The effect of $\mathrm{NaCl}$ on malt carboxypeptidase II: influence of the substrate structure on the $\alpha, \beta$ and $K$, values for $\mathrm{NaCl}$.

\begin{tabular}{lccc}
\hline Substrate & $\alpha$ & $\beta$ & $\begin{array}{l}\mathrm{K}_{\mathrm{s}} \text { or } \mathrm{Ki} \\
(\mathrm{M})\end{array}$ \\
\hline FA-Phe-OMe $^{\mathrm{ac})}$ & 0.06 & 1.0 & 6 \\
FA-Phe-OEt $^{\mathrm{a}}$ & 0.06 & 1.0 & 3 \\
FA-Ala-OEt $^{\mathrm{al}}$ & $<0.04$ & 2.5 & $>20$ \\
FA-Ala-OBzl $^{\mathrm{a})}$ & 0.19 & 1.0 & 1.3 \\
FA-Arg-OMe $^{\mathrm{a})}$ & 50 & 4 & 0.05 \\
FA-Ala-Lys-OH $^{\mathrm{b})}$ & 1.9 & 0.5 & 0.09 \\
\hline
\end{tabular}

The $\alpha, \beta$ and $K_{4}$ values (see Scheme 1) were calculated on the basis of $k_{r a t}$ and $K_{n 1}$ values, determined at a minimum of five different concentrations of $\mathrm{NaCl}$. a) The hydrolysis was carried out in $0.05 \mathrm{M}$-Hepes, $1 \mathrm{mM}$-EDTA, pH 7.5. b) the hydrolysis carried out in 0.05 M-Mes, 1 mM-EDTA, pH 6.75. c) with $\mathrm{Na}_{2} \mathrm{SO}_{4}$ the values for $\alpha, \beta$ and $K_{+}$are $0.06,1.0$ and $3 \mathrm{M}$. respectively. 
and 1.0, respectively, but the value for $\mathrm{K}_{\mathrm{A}}$ is $3 \mathrm{M}$ as compared with $6 \mathrm{M}$ for $\mathrm{NaCl}$.

\subsection{Malt carboxypeptidase II catalyzed peptide synthesis}

The ability of carboxypeptidase II to catalyze the aminolysis of $\mathrm{N}$-blocked amino acid esters has been investigated at $\mathrm{pH} 8.5$ where the enzyme remains stable for at least 4 hours. At this $\mathrm{pH}$ the enzyme exhibits maximal esterase and amidase activity and minimal peptidase activity (see Figure 1). The reaction was initially studied with $\mathrm{Bz}-\mathrm{Arg} \_\mathrm{OBu}$ as substrate and $\mathrm{H}$ Gly- $\mathrm{NH}_{2}$ as nucleophile. Two products were formed: Bz-Arg-OH and Bz-Arg-Gly- $\mathrm{NH}_{2}$ due to the partitioning of the acyl-enzyme intermediate between the hydrolysis reaction and the aminolysis reaction. The fraction undergoing aminolysis increased with increasing concentrations of H-Gly- $\mathrm{NH}_{2}$ but did not exceed 0.95 (data not shown). The fraction of aminolysis was constant at each concentration of nucleophile and thus essentially independent of the concentration of substrate remaining in the reaction mixture. However, the rate of substrate disappearance decreased significantly with increasing concentrations of $\mathrm{H}-\mathrm{Gly}-\mathrm{NH}_{2}$ indicating an inhibitor function of the nucleophile. The observation that the enzyme becomes saturated with nucleophile such that the fraction of aminolysis does not exceed 0.95 is compatible with the nucleophile binding to the acyl enzyme intermediate prior to the deacylation reaction. The capability of the enzyme to bind nucleophiles in this fashion may conveniently be estimated from the concentration of nucleophile required to produce a fraction of aminolysis which is half the maximal aminolysis fraction as previously described for carboxypeptidase I (7). This concentration is designated $\mathrm{K}_{\mathrm{N}(\mathrm{app})}$ since it is related to the dissociation constant of the complex between acyl-enzyme and nucleophile. Table VI lists the $\mathrm{K}_{\mathrm{N}_{(a p p)}}$ values for a series of amino acid amides. It is observed that $\mathrm{K}_{\mathrm{N(app)}}$ is identical (13 mM) for H-Gly- $\mathrm{NH}_{2}, \mathrm{H}-\mathrm{Ser}-\mathrm{NH}_{2}$ and $\mathrm{H}-\mathrm{Val}-\mathrm{NH}_{2}$ while it is only approximately $1 \mathrm{~mm}$ for $\mathrm{H}$-Lys- $\mathrm{NH}_{2}$ and $\mathrm{H}-\mathrm{Arg}-\mathrm{NH}_{2}$. The action of carboxypeptidase II on Bz-Arg-OBu in the presence of amino acids or amino acid
Table VI. Malt carboxypeptidase II catalyzed aminolysis of Bz-Arg-OBu using amino acids, amino acid amides and amino acid methyl esters as nucleophiles.

\begin{tabular}{|c|c|c|}
\hline Nucleophile & $\begin{array}{l}\text { Maximum fraction } \\
\text { of aminolysis }\end{array}$ & $\begin{array}{l}K_{N(a p p)} \\
(M)\end{array}$ \\
\hline H-Gly-NH & 0.95 & 0.013 \\
\hline $\mathrm{H}-$ Ser-NH $\mathrm{NH}_{2}$ & 0.85 & 0.013 \\
\hline $\mathrm{H}-\mathrm{Val}-\mathrm{NH}_{2}$ & 0.90 & 0.013 \\
\hline $\mathrm{H}-\mathrm{Arg}-\mathrm{NH}{ }_{2}$ & 0.75 & -0.001 \\
\hline H-Lys- $\mathrm{NH}_{2}$ & 0.85 & -0.001 \\
\hline $\mathrm{H}-\mathrm{Gly}-\mathrm{OH}^{\mathrm{a}}$ & $0.65(3.0 \mathrm{M})$ & \\
\hline $\mathrm{H}-\mathrm{Ser}-\mathrm{OH}^{\mathrm{a}}$ & $0.50(3.0 \mathrm{M})$ & \\
\hline $\mathrm{H}-\mathrm{Val}-\mathrm{OH}^{\mathrm{a}}$ & $0.30(0.5 \mathrm{M})$ & \\
\hline $\mathrm{H}$-Gly-OMe $\mathrm{e}^{\mathrm{a})}$ & $0.40(3.0 \mathrm{M})$ & \\
\hline $\mathrm{H}-\mathrm{Ser}-\mathrm{OMe} \mathrm{e}^{\mathrm{a}}$ & $0.25(3.0 \mathrm{M})$ & \\
\hline H-Val-OMe ${ }^{a)}$ & $0.55(1.0 \mathrm{M})$ & \\
\hline
\end{tabular}

Conditions: 2 mM-Bz-Arg-OBu, 5 mm-EDTA, 0.4 $4 \mu \mathrm{M}$-carboxypeptidase II. Reaction time: $5-50 \mathrm{~min}$. a) Saturation with these nucleophiles could not be obtained.

methyl esters also yields aminolysis products but with these nucleophiles a maximum of aminolysis could not be reached. The values obtained at the highest concentrations of nucleophile

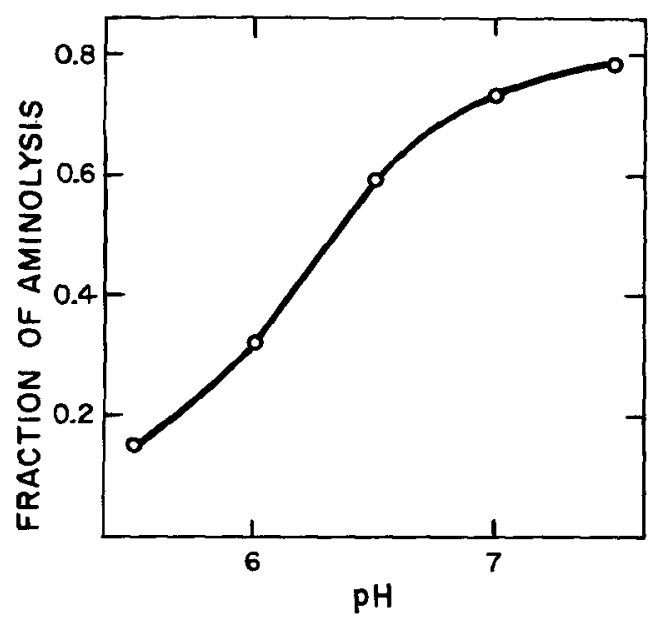

Figure 9. The influence of $\mathrm{pH}$ on the fraction of aminolysis in carboxypeptidase II catalyzed transpeptidation reactions. Reaction conditions: 2 mM-Bz-LysAla-OH, $5 \mathrm{~mm}$-EDTA, $1 \mathrm{~m}-\mathrm{H}-\mathrm{Gly}-\mathrm{NH}_{2}$, containing $0.12 \mu \mathrm{M}$ (pH 5.5), 0.20 $\mu \mathrm{M}(\mathrm{pH} \mathrm{6.0)}, 0.24 \mu \mathrm{M}(\mathrm{pH}$ $6.5), 0.55 \mu \mathrm{M}(\mathrm{pH} 7.0)$ or $0.80 \mu \mathrm{M}(\mathrm{pH} 7.5)$ carboxypeptidase II. Reaction time: $25-80 \mathrm{~min}$. 
tested are somewhat lower $(0.25-0.65)$ than those obtained with amino acid amides (Table VI).

The ability of malt carboxypeptidase II to catalyze transpeptidation reactions was initially studied with the excellent substrate Bz-Lys-Ala$\mathrm{OH}\left(\mathrm{k}_{\text {rat }}=2000 \mathrm{~min}^{-1}, \mathrm{~K}_{\mathrm{m}}=0.12 \mathrm{mM}\right)$ and with H-Gly- $\mathrm{NH}_{2}(1 \mathrm{M})$ as nucleophile. Two products were formed: Bz-Lys-OH and Bz-Lys-Gly- $\mathrm{NH}_{2}$ and at $\mathrm{pH} 5.5$ the fraction of aminolysis was only 0.15 but this value increased with $\mathrm{pH}$ to 0.80 at $\mathrm{pH} 7.5$ (Figure 9). It was not feasible to increase $\mathrm{pH}$ further due to the decreased peptidase activity at basic $\mathrm{pH}$ values. An increase in the concentration of $\mathrm{H}-\mathrm{Gly}-\mathrm{NH}_{2}$ to $2 \mathrm{M}$ did not increase the fraction of aminolysis at $\mathrm{pH} 7.5$ but at acidic $\mathrm{pH}$ it was increased significantly suggesting that the enzyme was not saturated with nucleophile in this $\mathrm{pH}$ range. With $\mathrm{H}-\mathrm{Val}-\mathrm{NH}_{2}, \mathrm{H}-\mathrm{Thr}-\mathrm{NH}_{2}$ or $\mathrm{H}-\mathrm{Ser}-\mathrm{NH}_{2}$ as nucleophiles and Bz-Lys-Ala-OH as substrate the fractions of aminolysis at $\mathrm{pH} 7.5$ were 0.70 , 0.85 and 0.80 , respectively.

The influence of the nature of the C-terminal amino acid residues of the peptide substrate on the fraction of aminolysis was studied with a series of Z-Ala-X-OH substrates ( $\mathrm{X}=$ amino acid residue) using $\mathrm{H}-\mathrm{Gly}-\mathrm{NH}_{2}$ as nucleophile
(Table VII). It is seen that the fractions of aminolysis are high $(0.80-0.90)$ when $X=G l y$, Ala or Ser while they are low $(0.15-0.35)$ for all the other substrates.

\section{DISCUSSION}

It is characteristic for the serine carboxypeptidases thus far investigated that they hydrolyse peptides with an acidic $\mathrm{pH}$ optimum while they act on substrates with blocked C-terminus, i.e. peptide esters and amides, with a basic $\mathrm{pH}$ optimum (13). With malt carboxypeptidase II $\mathrm{k}_{\text {cat }}$ for peptide hydrolysis correlates with the deprotonation of a group with a $\mathrm{pK}_{\mathrm{a}}$ around 4 and the protonation of a group with a $\mathrm{pK}_{\mathrm{a}}$ around 7 . The fact that $\mathrm{k}_{\text {cat }}$ for ester hydrolysis is constant in the $\mathrm{pH}$ range 4.6 to 8.7 precludes the involvement of a group with a $\mathrm{pK}_{\mathrm{a}}$ around 7 in ester hydrolysis but the significance of a group with a $\mathrm{pK}_{\mathrm{a}}$ around 4 cannot be established since the kinetic constants could not be determined below $\mathrm{pH}$ 4.6. However, it is probable that a common group determines both activities as in the case of carboxypeptidase $\mathrm{Y}(2,8)$ but with the important difference that it exhibits a $\mathrm{pK}_{\mathrm{a}}$ around 4 in carboxypeptidase II as compared with 5.5 in carboxypeptidase $\mathrm{Y}$. The

Table VII. The influence of the substrate structure on the fraction of aminolysis in malt carboxypeptidase II catalyzed aminolysis reactions using $\mathrm{H}-\mathrm{Gly}-\mathrm{NH}_{2}$ as nucleophile.

\begin{tabular}{lccl}
\hline Substrate & $\begin{array}{l}\text { enzyme } \\
\text { conc. } \\
(\mu \mathrm{M})\end{array}$ & $\begin{array}{l}\text { reaction time } \\
(\mathrm{min})\end{array}$ & $\begin{array}{l}\text { fraction of aminolysis } \\
(\text { Z-Ala-Gly-NH })^{2}\end{array}$ \\
\hline Z-Ala-Gly-OH & 7.5 & 500 & 0.80 \\
Z-Ala-Alà-OH & 1.5 & 90 & 0.90 \\
Z-Ala-Ser-OH & 1.5 & 270 & 0.90 \\
Z-Ala-Arg-OH & 3.7 & 10 & 0.35 \\
Z-Ala-Lys-OH & 3.7 & 12 & 0.15 \\
Z-Ala-Pro-OH & 28 & 120 & 0.20 \\
Z-Ala-Asn-OH & 1.5 & 35 & 0.35 \\
Z-Ala-His-OH & 1.5 & 80 & 0.35 \\
Z-Ala-Val-OH & 3.7 & 30 & 0.35 \\
Z-Ala-Met-OH & 14 & 15 & 0.20 \\
Z-Ala-Phe-OH & 14 & 80 & 0.20 \\
Z-Ala-Asp-OH & 28 & 300 & - \\
\hline
\end{tabular}

Conditions: $20 \mathrm{~mm}$ substrate, $1 \mathrm{M}-\mathrm{H}-\mathrm{Gly}-\mathrm{NH}_{2}, 5 \mathrm{~mm}-\mathrm{EDTA}$, pH 7.5 .

- indicates that no reaction has taken place. 
inactivation of serine carboxypeptidases with diisopropylfluorophosphate suggests mechanistic similarities with the serine endopeptidases and consequently, these groups should be histidyl residues (13). However, alternative mechanisms are possible, in particular since $a \mathrm{pK}_{a}$ of 4 as observed for carboxypeptidase II is unusually low for a histidyl residue.

$\mathrm{K}_{\mathrm{m}}$ for peptide hydrolysis appears to be dependent on the protonation of a group with $\mathrm{pK}_{\mathrm{a}}$ $>7$ as observed in carboxypeptidase $Y$ and it is probable that it at low $\mathrm{pH}$ functions as a positively charged binding site for the negatively charged carboxylate group of peptide substrates. Consistent with this, $K_{m}$ for hydrolysis of ester substrates, containing blocked carboxyl groups, is essentially constant above pH 6 and the different $\mathrm{pH}$ optima of $\mathrm{k}_{\mathrm{cat}} / \mathrm{K}_{\mathrm{m}}$ for hydrolysis of esters ( $\mathrm{pH}>7.5)$ and peptides $(\mathrm{pH}<4)$ are consequently due to different $\mathrm{pH}$ dependencies of $\mathbf{K}_{\mathrm{m}}$. Since similar differences were observed with carboxypeptidase $\mathrm{Y}(2,8)$, this is possibly general for serine carboxypeptidases.

The influence on $\mathrm{k}_{\text {cat }}$ of the alcohol leaving group of ester series Bz-Arg $\mathrm{O}^{\mathrm{OMe}},-\mathrm{OEt},-\mathrm{OBu}$, indicates that the deacylation step is not ratelimiting in ester hydrolysis in accordance with the observations for malt carboxypeptidase I (4) and carboxypeptidase Y (2).

The malt carboxypeptidase II catalyzed hydrolysis of ester substrates with the general formula $\mathrm{Bz}-\mathrm{X}$-OMe indicates a wide specificity with preference for substrates where $X=$ Phe, Arg, Lys over those where the X-position is occupied by an amino acid residue with an uncharged aliphatic or acidic side-chain. The high $\mathrm{k}_{\text {cat }} / \mathrm{K}_{\mathrm{m}}$ value for the hydrolysis of Bz-PheOMe is mainly due to a high $\mathrm{k}_{\text {cal }}$ value while for Bz-Arg $\mathfrak{O M M e}^{\mathrm{O}}$ and Bz-Lys-OMe it is mainly due to a low $K_{m}$ value. The previous study with peptide substrates of the general formula Z-Ala $\mathrm{X}-\mathrm{OH}$ indicated a wide specificity with preference for substrates where $X=A r g$, Lys or hydrophobic amino acid residues (9). Thus, malt carboxypeptidase II possesses the ability to hydrolyse substrates containing either hydrophobic or positively charged amino acid residues on both the $\mathrm{P}_{1}$ and the $\mathrm{P}_{1}^{\prime}$ positions. This is hardly consistent with the general understanding that a proteolytic enzyme contains only a single

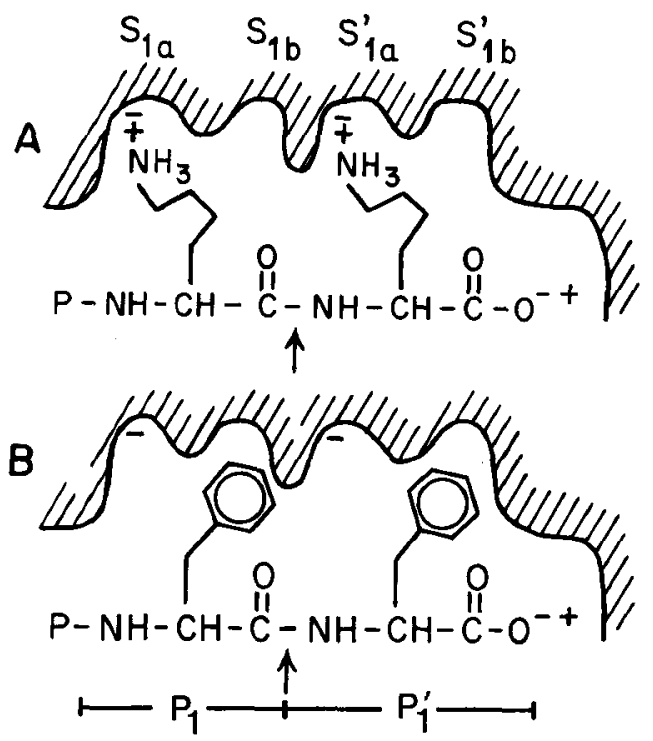

Figure 10. Schematic representation of the binding regions in malt carboxypeptidase II. The binding notation is that of SCHECHTER and BERGER (see abbreviations), and the dead-end structure is assumed to account for the exo-peptidase activity of the enzyme. (A) shows a proposed binding mode of a peptide with lysyl residues in the $P_{1}$ and $P_{1}^{\prime}$ positions. It is assumed that the positively charged side-chains of Lys interact with negatively charged groups located in the $S_{1 \mathrm{a}}$ and $S_{1 \text { a }}$ portions of the $S_{1}$ and $S_{1}$ binding sites, respectively. (B) shows a proposed binding mode of an analogous peptide with phenylalanyl residues in these positions. Here it is assumed that the hydrophobic side-chains interact with the hydrophobic $S_{\mathrm{Ib}}$ and $S_{\mathrm{lb}}$ regions of the $S_{1}$ and $S_{\text {inding }}$ bites, respectively.

binding site for each position of the substrate. It is more likely that within the $S_{1}$ and the $S_{1}$ binding sites separate areas exist to secure the interaction with these side-chains of different nature. A postulated binding region of the active site of malt carboxypeptidase II, incorporating this hypothesis, is shown in Figure 10. It is assumed that the $S_{1 a}$ and $S_{1 a}$ portion of the $S_{1}$ and $S_{\mid}^{\prime}$ binding sites, respectively, contain negatively charged groups which interact with the positively charged side-chains of e.g. FA-Arg $\downarrow$ OMe and FA-Ala ${ }^{\downarrow}$ Lys-OH. The $S_{1 b}$ and $S_{1 b}$ portions, on the other hand, are assumed to be hydrophobic regions which provide the inter- 
action with hydrophobic side-chains of the substrate. Since the $K_{m}$ values for FA-Phe-OMe and FA-Ala-Phe-OH are significantly higher than for FA-Arg $₫$ OMe and FA-Ala $\downarrow$ Lys-OH, respectively, it would appear that the ionic interactions between substrate and enzyme are stronger than the hydrophobic interactions.

The observation that $\mathrm{NaCl}$ and $\mathrm{PhGu}$ inhibit the malt carboxypeptidase II catalyzed hydrolysis of substrates containing positively charged groups in the $\mathrm{P}_{1}$ or $\mathrm{P}_{1}^{\prime}$ positions and activate the hydrolysis of substrates containing hydrophobic groups in both positions support the hypothesis that each of the $S_{1}$ and $S_{1}$ binding sites are divided into two regions with affinities for basic $\left(S_{1 \mathrm{a}}\right.$ and $\left.S_{1 \mathrm{a}}^{\prime}\right)$ and hydrophobic $\left(S_{\mathrm{lb}}\right.$ and $S_{\text {lb }}$ ) amino acid residues, respectively. The hydrolysis of FA-Ala-Lys-OH is competitively inhibited by $\mathrm{PhGu}$, indicating that this substance completely abolishes this activity by preventing the interaction between the lysyl residue of the substrate and the $\mathrm{S}_{\mathrm{la}}$ binding site. The hydrolysis of FA-Arg $\_$OMe is only partially inhibited by $\mathrm{PhGu}$. At saturation with this substance $\mathrm{K}_{\mathrm{m}}$ for the hydrolysis of FA-Arg $\_$OMe is increased drastically suggesting an adverse effect of $\mathrm{PhGu}$ on the binding of this substrate to the enzyme. It is conceivable that the ionic interaction between enzyme and substrate, i.e. binding of the arginyl residue to the $S_{\mathrm{la}}$ binding site, is completely abolished at saturating concentrations of PhGu. Nevertheless, the enzyme retains an ability to hydrolyse FA-Arg $\searrow$ OMe and interestingly, with four fold higher $\mathrm{k}_{\text {cat }}$.

Binding of $\mathrm{PhGu}$ to malt carboxypeptidase II strongly activates its hydrolysis of substrates with hydrophobic groups on the $P_{1}$ and $P_{1}^{\prime}$ positions. With the ester substrates the results are consistent with a $\mathrm{K}_{\mathrm{A}}$ of $6.8 \mathrm{mM}$ and since this value is in fair agreement with the value for $\mathrm{K}_{\mathrm{i}}$ obtained for FA-Ala-Lys-OH (3 mM) and FA-Arg-OMe $(8 \mathrm{mM})$ it is probable that the activation observed with the uncharged ester substrates is due to binding of PhGu to the binding sites for charged amino acid residues, i.e. to the $S_{1 \mathrm{a}}$ and $S_{\mathrm{la}}$ binding sites. The ionic nature of the binding of PhGu to the enzyme is supported by the fact that in the presence of $1 \mathrm{M}-\mathrm{NaCl}$, saturation of the enzyme with $\mathrm{PhGu}$ cannot be obtained, i.e. the activating effect of PhGu on the hydrolysis of FA-Phe$\mathrm{OMe}$ is negligible. It appears that the enzyme saturated with $\mathrm{PhGu}$ hydrolyses substrates containing bulky/hydrophobic groups in either the $\mathrm{P}_{\mathbf{I}}$ (Phe) or $\mathrm{P}_{\mathfrak{i}}^{\prime}(-\mathrm{OBzl})$ positions with significantly reduced $K_{m}$. This suggests that such groups when bound to the $S_{1 b}$ or $S_{1 b}$ sites interact with the phenyl group of the PhGu bound at

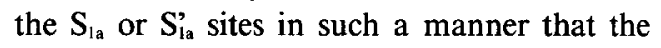
binding of these substrates is increased. When non-bulky groups are bound to both the $S_{1 b}$ and $S_{\mathrm{lb}}$ binding sites, viz. FA-Ala-OEt, the interaction with the $\mathrm{PhGu}$ appears to increase $\mathrm{k}_{\text {cat }}$ rather than to increase binding of the substrate.

It would be expected that binding of $\mathrm{PhGu}$ to the $S_{1 \mathrm{a}}$ and $S_{1 \mathrm{a}}$ sites influenced the hydrolysis

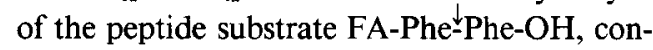
taining hydrophobic amino acid residues on both the $P_{1}$ and the $P_{1}^{\prime}$ positions, in a manner similar to that observed for the ester substrates containing bulky/hydrophobic groups. However, a similar decrease in $K_{m}$ and increase in $\mathbf{k}_{\mathrm{cat}}$ is observed only at low concentrations of $\mathrm{PhGu}$; at higher concentrations an apparent third binding mode of $\mathrm{PhGu}$ reduces the activity of the enzyme towards this substrate. This inhibition $\left(\mathrm{K}_{\mathrm{i}}-20 \mathrm{mM}\right)$ is uncompetitive, i.e. $\mathrm{PhGu}$ binds in this mode only to the enzyme-substrate complex. The activities of malt carboxypeptidase II towards other peptide and peptide amide substrates, i.e. FA-Ala-Phe-OH, FA-Phe-Gly$\mathrm{OH}$, FA-Phe-Ala-OH, FA-Phe-Val-OH, FAPhe-Gly- $\mathrm{NH}_{2}$ and FA-Phe-Val- $\mathrm{NH}_{2}$, are similarly activated at low concentrations and inhibited at high concentrations of $\mathrm{PhGu}$. The hydrolysis of FA-Phe- $\mathrm{NH}_{2}$ is also activated at low concentrations of $\mathrm{PhGu}$ but it is not inhibited at high concentrations. Thus, the uncompetitive mode of inhibition is observed only when the $P_{1}^{\prime}$ position is occupied by an amino acid or an amino acid amide.

It appears that the $S_{1 a}$ and $S_{l a}$ binding sites also may be saturated with $\mathrm{NaCl}$ with the consequence that the activities towards FA-Arg $₫$ $\mathrm{OMe}$ and FA-Ala-Lys-OH are partially inhibited. The $K_{i}$ values are $50 \mathrm{mM}$ and $90 \mathrm{~mm}$ for FA-Arg $\lfloor$ OMe and FA-Ala $\downarrow$ Lys-OH, respectively, and $\mathrm{NaCl}$ concentrations of that magnitude have very little influence on the activities towards substrates with hydrophobic amino 
acid residues on the $P_{1}$ and $P_{i}^{\prime}$ positions. However, at much higher concentrations of $\mathrm{NaCl}$ the hydrolysis of uncharged ester substrates is activated, mainly due to a decrease in $\mathrm{K}_{\mathrm{m}}$. This activation is consistent with $\mathrm{NaCl}$ functioning as a non-essential activator for the hydrolysis of uncharged substrates by binding to the enzyme according to Scheme 1. However, since $K_{A}$ is dependent on the nature of the substrate this interpretation is probably not correct. It is more probable that the increased ionic strength of the assay medium amplifies the hydrophobic interaction between enzyme and substrate and the $\mathrm{K}_{\mathrm{A}}$ is then only a measure for the concentration of $\mathrm{NaCl}$ at which this effect becomes significant. This is consistent with the magnitude of $K_{A}$ being related to the solubility of the substrate with the lowest values being observed with the least soluble substrate, i.e. FA-Ala OBzl. For $\mathrm{Na}_{2} \mathrm{SO}_{4}$ the value of $\mathrm{K}_{\mathrm{A}}$ is only $3 \mathrm{M}$ with FA-Phe $₫$ OMe as substrate as compared with $6 \mathrm{M}$ for $\mathrm{NaCl}$ consistent with the decreased solubility of the substrate in $\mathrm{Na}_{2} \mathrm{SO}_{4}$.

The action of malt carboxypeptidase II on peptide esters in the presence of amino acids or amino acid derivatives indicate that these substances compete with water as nucleophiles in the deacylation of the acyl-enzyme intermediate. The saturation phenomena observed with amino acid amides further indicate that these are bound to the acyl-enzyme intermediate prior to their participation in the deacylation reaction in analogy with previous observations with malt carboxypeptidase I (7). It is probable that the aminolysis reaction with amino acids and amino acid methyl esters involve a similar binding step but the high dissociation constant of these complexes $\left(K_{N(a p p)}\right)$ make the demonstration of this impossible. Assuming that amino acid amides are bound to the same site as the leaving group in the acylation reaction, i.e. the $S_{1}^{\prime}$ binding site, the results with different amino acid amides support a division of this binding site into two regions with the one, presumably the $S_{1 \mathrm{a}}$ binding site, providing tight ionic binding of $\mathrm{H}-\mathrm{Lys}-\mathrm{NH}_{2}$ and $\mathrm{H}-\mathrm{Arg}-\mathrm{NH}_{2}$. The other region of the $S_{1}^{\prime}$ binding site provides a much less tight binding of amino acid amides containing uncharged side-chains. However, this region cannot be assigned to the $S_{\mathrm{b}}$ site since the hydro- phobic properties of this site would have predicted better binding of $\mathrm{H}-\mathrm{Val}-\mathrm{NH}_{2}$ than of $\mathrm{H}$-Ser- $\mathrm{NH}_{2}$ and $\mathrm{H}$-Gly- $\mathrm{NH}_{2}$ while in fact, all these uncharged nucleophiles exhibit identical $\mathrm{K}_{\mathrm{N}(\mathrm{app})}$. A similar lack of dependence on the side-chain of amino acid amides has previously been observed in malt carboxypeptidase I catalyzed aminolysis reactions (7).

The specificities of malt carboxypeptidases I (4) and II thus indicate that both enzymes contain $S_{\mid}$binding sites with separate binding regions for positively charged and uncharged amino acid side-chains. The $S_{1}$ binding site appears only to be divided in carboxypeptidase II since carboxypeptidase I essentially is unable to hydrolyse peptides containing C-terminal Arg or Lys (3).

The specificity of carboxypeptidase $Y$ towards the C-terminus of peptide chains and its ability to catalyze aminolysis of peptide esters using amino acids or amino acid derivatives as amine components has rendered this enzyme a useful tool in the step-wise synthesis of polypeptides $(1,18,19,20)$. In addition, when the enzyme acts on polypeptides in the presence of nucleophiles it catalyzes transpeptidation reactions, i.e. the incorporation of the nucleophile in place of the C-terminal amino acid residue. This reaction can be utilized to alter the C-terminal amino acid residue, e.g. the conversion of porcine insulin to human insulin (12), to convert peptides, e.g. those obtained by genetic engineering, to peptide amides, or to incorporate various probes into peptides and proteins $(10,11)$. However, carboxypeptidase $\mathrm{Y}$ with a preference for hydrophic amino acid residues on the $P_{1}$ and $P_{\text {' position }}(2,3)$ is not suitable for the synthesis and semisynthesis of all peptide bonds. Although chemically modified derivatives of this enzyme with altered specificities may be useful for many reactions and among these the semisynthesis of human insulin (6) a demand exists for serine carboxypeptidases with specificities which can supplement that of carboxypeptidase Y. One such alternative is malt carboxypeptidase II since it is available in large quantities (9). The results presented in this paper indicate that this enzyme is particularly suited in the synthesis of peptide bonds where a basic amino acid residue donates the acyl portion and/or the 
imine portion. The aminolysis reactions of $\mathrm{Bz}-$ Arg-OBu using a number of different nucleophiles including $\mathrm{H}$-Arg- $\mathrm{NH}_{2}$ and $\mathrm{H}$-Lys- $\mathrm{NH}_{2}$ are examples of how the enzyme can be employed in the step-wise synthesis of such peptides, and the transpeptidation reactions with Bz-Lys-Ala$\mathrm{OH}$ using a series of amino acid amides as nucleophiles are examples of how it can be employed in the semisynthesis of peptides and proteins.

\section{ACKNOWLEDGEMENTS}

Professor MARTIN OTTESEN is thanked for stimulating discussions and revision of the manuscript. The excellent technical assistance of Ms. IRENE SIMONSEN is gratefully acknowledged.

\section{REFERENCES}

1. BREDDAM. K.. F. WIDMER \& J. T. JOHANSEN: Influence of the substrate structure on carboxypeptidase Y catalyzed peptide bond formation. Carlsberg Res. Commun. 45, 361-367 (1980)

2. BREDDAM, K.: Modification of the single sulfhydryl group of carboxypeptidase $\mathrm{Y}$ by mercurials. Influence on enzyme specificity. Carlsberg Res. Commun. 48, 9-19 (1983)

3. Breddam, K., S. B. Sørensen \& M. Ottesen: Isolation of a carboxypeptidase from malted barley by affinity chromatography. Carlsberg Res. Commun. 48, 217-230 (1983)

4. BREDDAM, K. \& M. OtTESEN: Influence of guanidine derivatives on the specificity of malt carboxypeptidase I. Carlsberg Res. Commun. 48, 573582 (1982).

5. Breddam, K.. J. T. Johansen \& M. Ottesen: Carboxypeptidase $\mathrm{Y}$ catalyzed transpeptidation and condensation reactions. Carlsberg Res. Commun. 49, 457-462 (1984)

6. BREDDAM, K. \& J. T. JohanSEN: Semisynthesis of human insulin utilizing chemically modified carboxypeptidase Y. Carlsberg Res. Commun. 49, 463-472 (1984)

7. BreddaM, K. \& M. OtTESEN: Malt carboxypepti- dase I catalyzed aminolysis reactions. Carlsberg Res. Commun. 49, 473-481 (1984)

8. BREDDAM, K : Chemically modified carboxypeptidase $Y$ with increased amidase activity. Carlsberg Res. Commun. 49, 535-554 (1984)

9. Breddam, K., S. B. Sørensen \& M. Ottesen: Isolation of carboxypeptidase II from malted barley by affinity chromatography. Carlsberg Res. Commun. 50, 199-209 (1985)

10. BreddaM, K., F. Widmer \& J. T. Johansen: Carboxypeptidase $Y$ catalyzed transpeptidations and enzymatic peptide synthesis. Carlsberg Res. Commun. 45, 237-247 (1980)

11. Breddam, K., F. Widmer \& J. T. Johansen: Carboxypeptidase $\mathrm{Y}$ catalyzed C-terminal modifications of peptides. Carlsberg Res. Commun. 46, 121-128 (1981)

12. BReddam, K., F. Widmer \& J. T. Johansen: Carboxypeptidase $\mathrm{Y}$ catalyzed C-terminal modification in the B-chain of porcine insulin. Carlsberg Res. Commun. 46, 361-372 (1981)

13. BREDDAM, K: Serine carboxypeptidases, their distribution, function and catalytic properties. A review. Carlsberg Res. Commun. (to be published)

14. Mikola. L.: Germinating barley grains contain five acid carboxypeptidases with complementary substrate specificities. Biochem. Biophys. Acta 747, 241-252 (1983)

15. Rohrbach, M. S., E. B. Williams \& R. A. ROLSTED: Purification and substrate specificity of bovine angiotensin-converting enzyme. J. Biol. Chem. 256, 225-230 (1981)

16. Schechter, J. \& B. Berger: On the size of the active site of proteases. I. papain. Biochem. Biophys. Res. Commun. 27, 157-162 (1967)

17. SEgel, J. H.: Enzyme Kinetics pp. 227-231, WileyInterscience, New York (1975)

18. WidMER, F. \& J. T. JoHANSEN: Enzymatic peptide synthesis. Carboxypeptidase Y catalyzed formation of peptide bonds. Carlsberg Res. Commun. 44, 37-46 (1979)

19. Widmer, F.. K. Breddam \& J. T. Johansen: Carboxypeptidase $Y$ catalyzed peptide synthesis using amino acid alkyl esters as amine components. Carlsberg Res. Commun. 45, 453-463 (1980)

20. WidMER,F., K. BREDDAM \& J. T. Johansen: Influence of the structure of amine components in carboxypeptidase $\mathrm{Y}$ catalyzed amide bond formation. Carlsberg Res. Commun. 46, 97-106 (1981)

Accepted by $\mathrm{H}$. KLENOW 